\title{
TOTAL PHENOLIC CONTENT AND ANTIOXIDANT ACTIVITIES OF BUNI FRUIT (ANTIDESMA BUNIUS L.) IN MONCONGLOE MAROS DISTRICT EXTRACTED USING ULTRASOUND-ASSISTED EXTRACTION
}

\author{
M. Yasser ${ }^{1, *}$, M. Rafi ${ }^{2}$, W.T. Wahyuni ${ }^{2}$, S.E. Widiyanti ${ }^{1}$ and A.M.I.A Asfar ${ }^{1}$ \\ ${ }^{1}$ Department of Chemical Engineering, Politeknik Negeri Ujung Pandang, Makassar-90254, \\ South Sulawesi, Indonesia \\ ${ }^{2}$ Department of Chemistry, Faculty of Mathematics and Natural Sciences, Bogor Agricultural \\ University, Bogor-16880, West Java, Indonesia. \\ *E-mail : myasser@poliupg.ac.id
}

\begin{abstract}
This study aims to extract Buni Fruit obtained from Moncongloe, Maros district, South Sulawesi, Indonesia, using Ultrasound-Assisted Extraction technology with ethanol as solvent. The effect of extraction temperature on the Total Phenolic Content and Antioxidant Activities of the extract was also studied. The result shows that at the temperature of $50^{\circ} \mathrm{C}$ was obtained the best extract with the Total Phenolic Content of $6.7415 \pm 0.0721 \mathrm{mg} / \mathrm{g}$ in GAE and the value of $\mathrm{IC}_{50}$ of $29.9618 \pm 1.9521 \mathrm{mg} / \mathrm{L}$. This result shows that Buni fruit extract has the potential to be developed as a healthy food.
\end{abstract}

Keywords: Buni Fruit, Ultrasound-Assisted Extraction, Total Phenolic Content, Antioxidant Activities, Ethanol

(C) RASĀYAN. All rights reserved

\section{INTRODUCTION}

Buni fruit (Antidesma bunius L.) is a traditional plant spread all over South Sulawesi; this includes Moncongloe, Maros district. Buni fruit is used as a natural food coloring due to its unique color ${ }^{1}$. The redpurples color of Buni fruit indicates the content of the flavonoid compound in Buni fruit. Flavonoid has various health benefits ${ }^{2}$ such as antioxidant ${ }^{3}$, antimicrobial ${ }^{4}$, and anti-inflammatory agent. ${ }^{5,6}$

Various methods have been to obtain the extract of flavonoids. The common method used in the extraction process is maserasi. ${ }^{7}$ Recently, ultrasound-assisted technology has been developed as an extraction method. ${ }^{8}$ The advantages of extraction using ultrasound technology are low cost, faster, simple process, save energy and more efficient. Ultrasound technology can also increase the yield of extraction due to the acoustic cavitations effect of ultrasound wave generated insolvent. The mechanical effect of ultrasound technology can increase the surface contact area between the solid phase and liquid phase also, it can accelerate the diffusion process of the dissolved compound from solid phase to solvent. ${ }^{9}$ Ultrasound-Assisted Extraction technology did not generate significant change in chemical structures and raw material used. ${ }^{10}$ Ultrasound-Assisted Extraction technology can also facilitate effective mixing, faster energy transfer, reduce thermal gradient and extraction temperature, selective extraction, faster response and higher yield. ${ }^{11-13}$

Abundant to be Buni fruits in Moncongloe, Maros district, potentially developed to be extracted as an antioxidant. Ultrasound technology utilization in the extraction process can increase extraction yield and efficiency, compared to the conventional extraction method. For this reason, this study was aimed to was investigated Total phenolic content and antioxidant activities from the extract of Buni fruit obtained from Moncongloe, Maros district. The results also were characterized by UV-Vis spectroscopy and IR spectroscopy.

Rasayan J. Chem., 13(1), 684-689(2020)

http://dx.doi.org/10.31788/RJC.2020.1315584 
RASĀYAN J. Chem.

Vol. 13 | No. 1 |684-689| January - March | 2020

\section{Plant Material}

\section{EXPERIMENTAL}

Buni fruit (Antidesma bunius L.) was obtained from Moncongloe, Maros district, South Sulawesi, Indonesia, in April, 2019. Buni fruit is ripe fruit with a deep red color (burgundy). Buni fruit's flesh and seeds were separated, and then its flesh was extracted.

\section{Materials}

All the chemicals i.e. Ethanol $\left(\mathrm{C}_{2} \mathrm{H}_{5} \mathrm{OH}\right)$, Folin-Ciocalteau Phenol, Sodium Carbonate $\left(\mathrm{Na}_{2} \mathrm{CO}_{3}\right)$, Gallic Acid were purchased from Merck, and 2,2-diphenyl-1-picrylhydrazyl (DPPH) was purchased from Sigma Aldrich.

\section{General Procedure}

\section{Buni fruit Ultrasound-Assisted Extraction}

$300 \mathrm{~g}$ of sample was added ethanol as a solvent to make the sample being soaked, after that it was extracted for $45 \mathrm{~min}$ by power sonic Ultrasound of 405 on a wave of $40 \mathrm{kHz} .^{8,13-14}$ The extraction was conducted by applying various temperatures to find out the effect of temperature. The extract was then filtered using a paper filter, then evaporated in low pressure and temperature that was no more than $45^{\circ} \mathrm{C}$ until thick extract obtained.

Table-1: The Variables of Experiment

\begin{tabular}{c|c|c}
\hline Samples & $\begin{array}{c}\text { Temperature of Ultrasound } \\
\text { Extraction }\left({ }^{\circ} \mathrm{C}\right)\end{array}$ & $\begin{array}{c}\text { The Time of Ultrasound } \\
\text { Extraction (Minutes) }\end{array}$ \\
\hline $\mathrm{A}$ & 40 & 45 \\
\hline $\mathrm{B}$ & 50 & 45 \\
\hline $\mathrm{C}$ & 60 & 45 \\
\hline
\end{tabular}

\section{Characterization of Extracts}

UV-Vis Spectroscopy Analysis

Buni fruit extract was measured by Orion Aquamate 8000 UV Vis spectroscopy in wavelength of 200 to $700 \mathrm{~nm} .{ }^{15}$ Characteristic peaks were obtained for the different functional groups.

\section{IR Spectroscopy Analysis}

The IR spectrum of Buni fruit extracted with ethanol solvent was measured by Prestige-21 Shimadzu Infrared spectroscopy at the range of $400-4000 \mathrm{~cm}^{3}$ using $\mathrm{KBr}$ pellet ${ }^{16}$ to identify its various functional group.

\section{Determination of the Total Phenolic Content}

The total phenolic content of Buni fruit extracted was measured using a reagent of Folin Ciocalteau. ${ }^{17} 1$ $\mathrm{mL}$ standard solution of Gallic Acid $(3,6,9,12,15,18$ and $21 \mathrm{mg} / \mathrm{L})$ it was added with I $\mathrm{mL}$ of FolinCiocalteu and $5 \mathrm{~mL} \mathrm{Na} \mathrm{CO}_{3} 10 \%$. The sample was then placed outside for 1 hour at room temperature. The absorbance of this solution was measured at the wavelength of $765 \mathrm{~nm}$ by using Orion Aquamate $8000 \mathrm{UV}$-Vis Spectroscopy. The same procedures were conducted to sample of buni fruit extracted with ethanol solvent. $1 \mathrm{~mL}$ of sample was added with a solvent in the same condition with a gallic acid standard curve.

\section{Antioxidant Activities}

Antioxidant activity was measured using DPPH (2,2-diphenyl-1-picrylhydrazyl) method. ${ }^{18,19,20} 2 \mathrm{~mL}$ of each sample of buni fruit extracted with ethanol solvent in concentration of $10,20,30,40$ and $50 \mathrm{mg} / \mathrm{L}$ was added with $2 \mathrm{~mL}$ DPPH $0,1 \mathrm{M}$. This solution was placed outside for 1 hour at the room temperature before being measured by Orion Aquamate $8000 \mathrm{UV}-$ Vis Spectroscopy at the wavelength of $517 \mathrm{~nm}$. $\mathrm{IC}_{50}$ (efficient concentration of extract to decrease initial DPPH radical concentration of 50\%) was obtained by interpolation in linear regression analysis. DPPH solution was used as the control. 
RASĀYAN J. Chem.

Vol. 13 | No. 1 |684 - 689| January - March | 2020

\section{RESULTS AND DISCUSSION}

\section{Characterization of Extract using UV-Vis Spectroscopy}

Buni fruit extract analysis conducted by UV-Vis Spectroscopy was aimed to predict secondary metabolite compounds contained in it. Each secondary metabolite compound had a unique absorbance that was measured by UV-Vis Spectroscopy. The result of sample analysis using UV-Vis Spectroscopy shows that there were two unique peaks (band) in each extract. Extract A represents two bands at an absorbance of $279 \mathrm{~nm}$ and $550 \mathrm{~nm}$, extract B represents on absorbance at $277 \mathrm{~nm}$ and $548.5 \mathrm{~nm}$ and extract C represents on absorbance at $278.5 \mathrm{~nm}$ and $548.5 \mathrm{~nm}$. Those three extracts were identified as flavonoid indicated by the formation of maximum absorbance at the range of 300 to $500 \mathrm{~nm}$ as a band I and the maximum absorbance at the range of 240 to $290 \mathrm{~nm}$ as band II. ${ }^{21,22}$

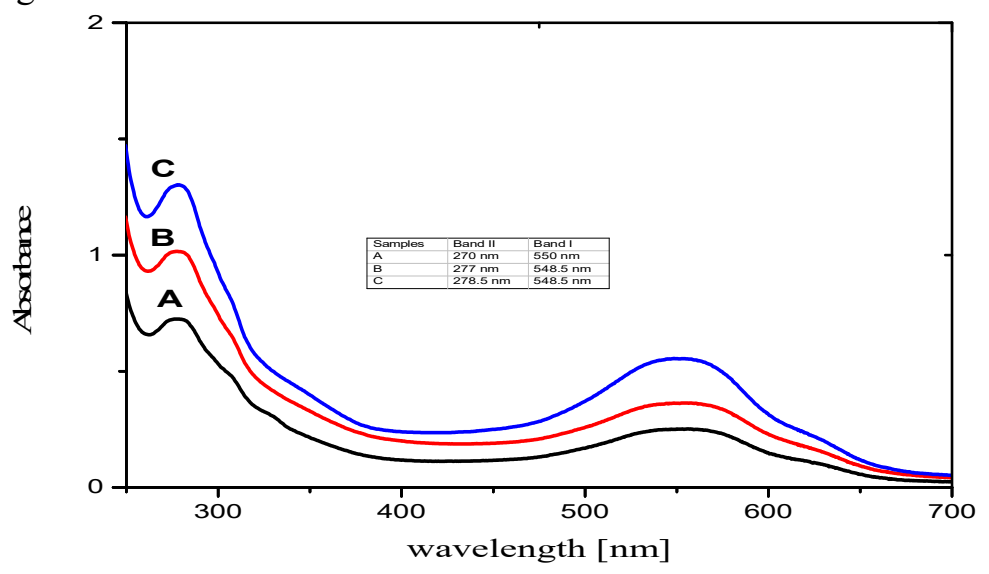

Fig.-1: UV-Vis Spectrum of Buni Fruits Extracted

\section{Characterization of Extract using IR Spectroscopy}

Buni fruit extract measurement was conducted by Infrared Spectroscopy to find out the functional groups contained in the extract. The measurement result (Fig.-2 and Table-2) shows that buni fruit extract contained an aromatic functional group shown in wavenumber of 1452.45 to1454.38 $\mathrm{cm}^{-1}$ as $\mathrm{C}=\mathrm{C}-\mathrm{C}$ aromatic. Also O-C-H bound was also identified in a form of phenolic on wave number of 1224.84 to $1238.34 \mathrm{~cm}^{-1}$. There was also a carbonyl functional group, $\mathrm{C}=\mathrm{O}$ indicated by the absorbance of wavenumber of 1708.99 to $1734.06 \mathrm{~cm}^{-1}$. The functional group of $-\mathrm{OH}$ was also identified with the unique wave number of 3421.83 to $3524.06 \mathrm{~cm}^{-1}$. The functional group contained in Buni fruit extract strengthen the extracted measurement by using UV-Vis Spectroscopy (Fig.-1) which identifies that buni fruit extract contained a flavonoid compound. Flavonoid compound was known to contain three rings which two of those are aromatic. It was also known that the flavonoid compound has a carbonyl functional group. Also, several derivatives of the flavonoid compound contain - $\mathrm{OH}$ functional group.

\begin{tabular}{c|c|c|c}
\multicolumn{4}{c}{ Table-2: Measurement Peaks Result of Buni Fruit Extract Analyzed by IR Spectroscopy } \\
\hline $\begin{array}{c}\mathrm{A} \\
{\left[\mathrm{cm}^{-1}\right]}\end{array}$ & $\begin{array}{c}\mathrm{B} \\
{\left[\mathrm{cm}^{-1}\right]}\end{array}$ & $\begin{array}{c}\mathrm{C} \\
{\left[\mathrm{cm}^{-1}\right]}\end{array}$ & Functional Group Assignment \\
\hline 1224.84 & 1238.34 & 1224.84 & $\mathrm{O}-\mathrm{C}-\mathrm{H}$ bending (phenolic) $)^{23-25}$ \\
\hline 1454.38 & 1452.45 & 1454.38 & $\mathrm{C}=\mathrm{C}-\mathrm{C}$ Aromatic \\
\hline 1647.26 & 1643.41 & 1643.41 & $\mathrm{C}=\mathrm{C}$ stretching of phenyl \\
\hline 1734.06 & 1708.99 & 1722.49 & Carbonyl compound, $\mathrm{C}=\mathrm{O}^{23-24,27}$ \\
\hline 3524.06 & 3421.83 & 3431.48 & $-\mathrm{OH}^{24-25,27}$ \\
\hline
\end{tabular}

\section{Total Phenolic Content}

The total phenolic content of buni fruit extract was measured by the Folin-Ciocalteau method. The result of total phenolic measurement shows that the extraction at the temperature of $50^{\circ} \mathrm{C}$ using ultrasound had total phenolic content of $6.7415 \pm 0.0721 \mathrm{mg} / \mathrm{g}$ in GAE, it was higher than a total phenolic content obtained extraction temperature of $40^{\circ} \mathrm{C}$ and $60^{\circ} \mathrm{C}$. Temperature of $50^{\circ} \mathrm{C}$ was the best temperature range in the extraction process to produce a high total phenol content and antioxidant activities. ${ }^{28}$ 
RASĀYAN J. Chem.

Vol. 13 | No. 1 |684-689| January - March | 2020

The result of buni fruit extract was analyzed by UV-Vis Spectroscopy (Fig.-1) and IR Spectroscopy (Fig.2 and Table-2) shows that buni fruit extract contained phenolic compound especially flavonoid. The total difference of phenolic content on the three temperature variations was caused by phenolic compound content in buni fruit extract. Several phenolic compounds were vulnerable to $\mathrm{pH}$ and high temperature. ${ }^{1,29,30}$

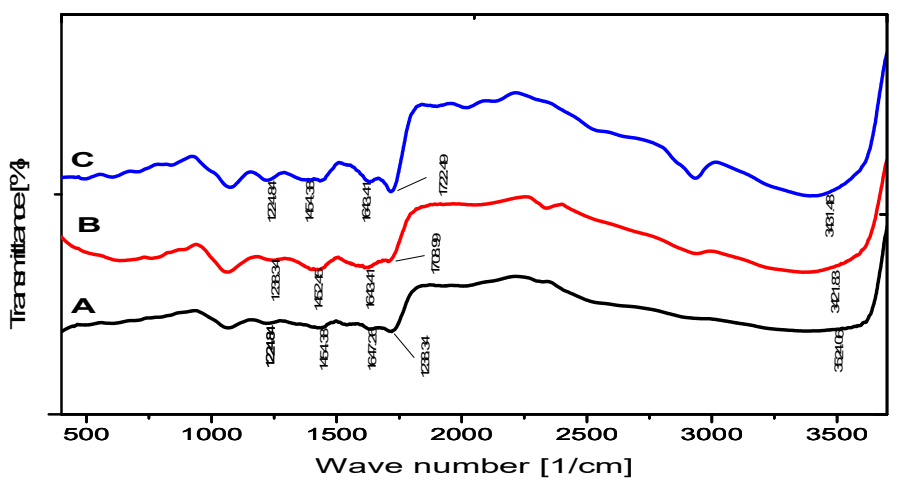

Fig.-2: IR Spectrum of Buni Fruits Extract

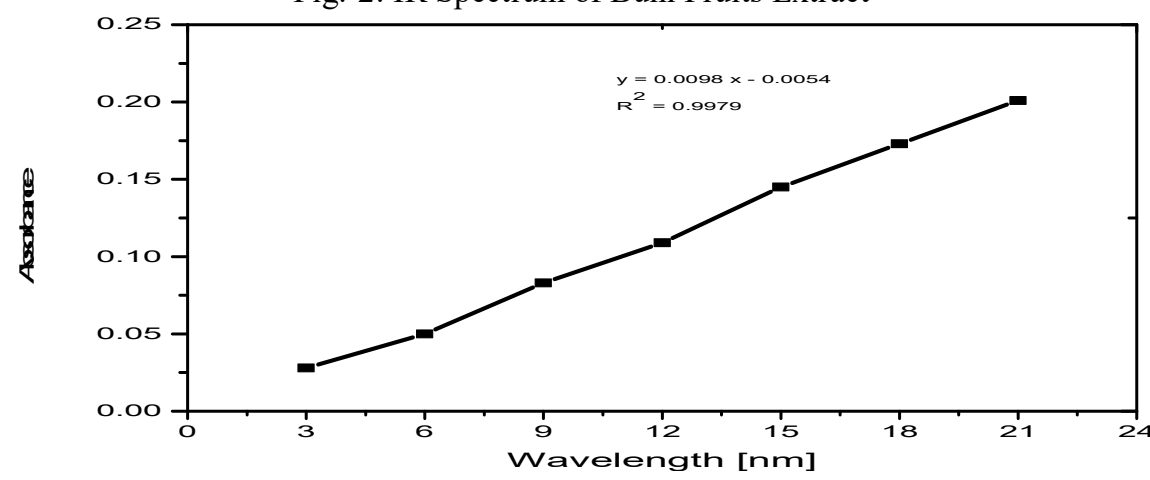

Fig.-3: Gallic Acid Calibration Curves at the Various Concentrations Table-3: Total Phenolic Content of Buni Fruits Extract

\begin{tabular}{c|c|c}
\hline Samples & Absorbance & \multirow{2}{*}{$\begin{array}{c}\text { Total Phenol Content } \\
(\mathrm{mg} / \mathrm{g} \text { in GAE*) }\end{array}$} \\
\hline A1 & 0.0470 & \multirow{2}{*}{$5.3571 \pm 0.0267$} \\
\cline { 1 - 2 } A2 & 0.0469 & \\
\hline A3 & 0.0474 & \multirow{2}{*}{$6.7415 \pm 0.0721$} \\
\hline B1 & 0.0500 & \\
\hline B2 & 0.0510 & \multirow{2}{*}{$5.6871 \pm 0.0589$} \\
\hline B3 & 0.0500 & \\
\hline C2 & 0.0500 & \\
\hline C3 & 0.0510 & \\
\hline
\end{tabular}

\section{Antioxidant Activities}

*GAE is Gallic Acid Equivalent

Antioxidant activities of buni fruit extract were measured by DPPH method. The ability of buni fruit extract used as an antioxidant was based on phenolic compound content $t^{30-32}$. The ability as an antioxidant can be seen by the value of $\mathrm{IC}_{50}{ }^{33}$

The value of $\mathrm{IC}_{50}$ in three ultrasound-assisted extraction temperature shows an insignificant difference. Extraction at the temperature of $50^{\circ} \mathrm{C}$ given better value of $\mathrm{IC}_{50}$ compared to the value obtained by extraction at the temperature of $40^{\circ} \mathrm{Cand} 60^{\circ} \mathrm{C}$. The value of $\mathrm{IC}_{50}$ was affected by the phenolic compound in the extract. The higher the total phenolic content, the stronger the antioxidant value of $\mathrm{IC}_{50}$ would be. The value of $\mathrm{IC}_{50}<50 \mathrm{mg} / \mathrm{L}$ indicates a strong antioxidant. ${ }^{34}$ Phenolic compound has antioxidant property 
RASĀYAN J. Chem.

Vol. 13 | No. 1 |684-689| January - March | 2020

because of its hydroxyl functional group leading to be able for hydrogen donor in the radical compound which made it stable. ${ }^{35,36}$

Table-4 : Antioxidant Activities of Buni Fruit Extract

\begin{tabular}{|c|c|c|c|c|}
\hline Samples & Linear Equations & $\mathrm{R}^{2}$ & $\mathrm{IC}_{50}(\mathrm{mg} / \mathrm{L})$ & $\begin{array}{l}\text { Average of } \mathrm{IC}_{50} \\
(\mathrm{mg} / \mathrm{L})\end{array}$ \\
\hline A1 & $\mathrm{y}=1.1039 \mathrm{x}+11.169$ & 0.9983 & 35.1762 & \multirow{3}{*}{$36.7707 \pm 1.3815$} \\
\hline $\mathrm{A} 2$ & $y=1.1948 x+5.0649$ & 0.9975 & 37.6089 & \\
\hline A3 & $y=1.2597 x+2.7273$ & 0.9948 & 37.5270 & \\
\hline $\mathrm{B} 1$ & $\mathrm{y}=1.2792 \mathrm{x}+14.481$ & 0.9923 & 27.7666 & \multirow{3}{*}{$29.9618 \pm 1.9521$} \\
\hline $\mathrm{B} 2$ & $\mathrm{y}=1.3831 \mathrm{x}+6.4286$ & 0.9983 & 31.5027 & \\
\hline B3 & $y=1.2662 x+11.234$ & 0.9849 & 30.6160 & \\
\hline $\mathrm{C} 1$ & $y=1.1558 x+13.636$ & 0.9960 & 31.4622 & \multirow{3}{*}{$32.8612 \pm 1.3668$} \\
\hline $\mathrm{C} 2$ & $\mathrm{y}=1.0649 \mathrm{x}+14.935$ & 0.9988 & 32.9280 & \\
\hline $\mathrm{C} 3$ & $y=1.2078 x+8.7013$ & 0.9877 & 34.1933 & \\
\hline
\end{tabular}

\section{CONCLUSION}

Buni fruit by Ultrasound-Assisted Extraction using ethanol solvent at the varying temperature of $40^{\circ} \mathrm{C}$, $50^{\circ} \mathrm{C}$ and $60^{\circ} \mathrm{C}$ produced extract that was identified as a flavonoid and its derivatives. The extract formed by three variations generated a high total phenolic content and strong antioxidant activities.

\section{ACKNOWLEDGMENT}

Our gratitude to the Ministry of Science, Technology, and Higher Education of Indonesia for financial support and also to Bogor Agricultural University especially to Analytical Chemistry Division which has cooperated with authors in conducting a research study.

\section{REFERENCES}

1. W. Suravanichnirachorn, V. Haruthaithanasan, S. Suwonsichon, U. Sukatta and W. Chantrapornchai, International Food Research Journal, 25, 6 (2018).

2. M. Kassem, A. Hashim, and H. Hassanein, European Scientific Journal,9, 18 (2013).

3. V. D'Amelia, R. Aversano, P. Chiaiese and D. Carputo, Phytochemistry Reviews, 17, 3 (2018), DOI: 10.1007/s11101-018-9568-y.

4. I. Górniak, R. Bartoszewski and J. Króliczewski, Phytochemistry Reviews,18, 1 (2019), DOI:10.1007/s11101-018-9591-z.

5. J. Hosek and K. Smejkal, M. Parnham (ed.), Encyclopedia of Inflammatory Diseases, Springer Basel. pp.,1-17 (2015), DOI:10.1007/978-3-0348-0620-6.

6. A. Kozłowska and D. Szostak-Węgierek, J.-M. Mérillon, K.G. Ramawat (eds.), Bioactive Molecules in Food, Reference Series in Phytochemistry, Springer International Publishing $A G$ 2018, pp. 53-78 (2019), DOI:10.1007/978-3-319-78030-6_54.

7. S. Arora and P.J. Itankar, Journal of Traditional and Complementary Medicine, 8, 4 (2018), DOI: $10.1016 /$ j.jtcme.2017.10.002.

8. M.M. Hasan, T. Bashir and H. Bae, Molecules, 22, 7(2017), DOI: 10.3390/molecules22071046.

9. T. Bin Zou, M. Wang, R.Y. Gan and W.H. Ling, International Journal of Molecular Sciences, 12, 5 (2011), DOI: 10.3390/ijms12053006.

10. L.L. Zheng, G. Wen, M.Y. Yuan and F. Gao, Journal of Chemistry,2016, (2016), DOI : $10.1155 / 2016 / 8768130$.

11. M.I. Ngaha Njila, E. Mahdi, D.M. Lembe, Z. Nde and Nyonseu, D., In 7th Int'l Conference on Agricultural, Chemical, Biological and Environmental Sciences (ACBES-2017) May 2224, 2017 Kuala Lumpur (Malaysia) Review, pp. 67-72 (2017), DOI:10.15242/IIE.C0517024.

12. Y. Wang, Y. Gao, H. Ding,S. Liu, X. Han, J. Gui and D. Liu, Food Chemistry,218, 1 (2017), DOI:10.1016/j.foodchem.2016.09.058. 
RASĀYAN J. Chem.

Vol. 13 | No. 1 |684-689| January - March | 2020

13. Z. Cai, Z. Qu, Y. Lan, Z.Zhao, X. Ma, Q. Wan, P. Jing and P. Li, Food Chemistry,197, 1 (2016), DOI: 10.1016/j.foodchem.2015.10.110.

14. R. Husen, Y. Andou, A. Ismail and Y. Shirai, The Malaysian Journal of Analytical Sciences, 18, 3 (2014).

15. P. Raji, A.V. Samrot, D.B. Rohan, M.D. Kumar, R. Geetika, V.K. Sharma and D.Keerthana, Rasayan Journal of Chemistry, 12, 1(2019), DOI: 10.31788/RJC.2019.1214054.

16. R. Tahir, A.W. Wahab, N.L. Nafie and I. Raya, Rasayan Journal of Chemistry,12, 3 (2019), DOI:10.31788/RJC.2019.1235306.

17. N. Siddiqui, A. Rauf, A. Latif and Z. Mahmood, Journal of Taibah University Medical Sciences, 12, 4 (2017), DOI: 10.1016/j.jtumed.2016.11.006.

18. M. Kurniasih, Purwati and R.S. Dewi, IOP Conference Series: Materials Science and Engineering, 349, 1(2018), DOI: 10.1088/1757-899X/349/1/012037.

19. N.Z. Ismail, H. Arsad, M.R. Samian and M.R. Hamdan, AGRIVITA Journal of Agricultural Science,39, 3(2017), DOI: 10.17503/agrivita.v39i3.1076.

20. E. Iqbal, K.A. Salim and L.B.L. Lim, Journal of King Saud University - Science, 27, 3 (2015), DOI: $10.1016 / \mathrm{j} . j \mathrm{ksus} .2015 .02 .003$.

21. M. Vihakas, Flavonoids and Other Phenolic Compounds: Characterization and Interactions With Lepidopteran and Sawfly Larvae. Methods in Polyphenol Analysis, Annales Universitatis Turkuensis, Finland, p. 13-15 (2014).

22. Y. Duan, Journal of Chemical and Pharmaceutical Research,6, 9 (2014).

23. S. Diblan, P. Kadiroglu and L.Y. Aydemir, Food and Health, 4, 2(2018), DOI: 10.3153/FH18008.

24. A.B.D. Nandiyanto, R. Oktiani, and R. Ragadita, Indonesian Journal of Science \& Technology,4, 1 (2019).

25. J. Coates, Encyclopedia of Analytical Chemistry, John Wiley \& Sons, Ltd, New York, USA, p. 8-14 (2006), DOI:10.1002/9780470027318.a5606.

26. X. Lu, J. Wang, H.M. Al-Qadiri, C.F. Ross, J.R. Powers, J. Tang and B.A. Rasco, Food Chemistry, 129, 2 (2011), DOI: 10.1016/j.foodchem.2011.04.105.

27. S.D. Silva, R.P. Feliciano, L.V. Boas and M.R. Bronze, Food Chemistry,150, (2014), DOI: 10.1016/j.foodchem.2013.11.028.

28. G.A. Akowuah, A. Mariam, and J.H. Chin, Pharmacognosy Magazine ,5, 17 (2009).

29. A. Altemimi, D.G. Watson, R. Choudhary, M.R. Dasari and D.A. Lightfoot, PLoS One, 11, 2 (2016), DOI: 10.1371/journal.pone.0148758.

30. K. Samavardhana, P. Supawititpattana, N. Jittrepotch, K. Rojsuntornkitti and T. Kongbangkerd, International Food Research Journal,22, 3 (2015).

31. S. Bahçeci, N. Yıldırım, Ö. Gürsoy-Kol, S. Manap, M. Beytur, and H. Yüksek, Rasayan Journal of Chemistry,9, 3 (2016).

32. M. Jun, H.Y. Fu, J. Hong, X. Wan, C.S. Yang and C.T. Ho, Journal of Food Science,68, 6 (2003), DOI: 10.1111/j.1365-2621.2003.tb07029.x.

33. S. Khomdram, S. Arambam, S. Barthakur and G.S. Devi, International Journal of Current Microbiology and Applied Sciences, 6, 4 (2017), DOI: 10.20546/ijcmas.2017.604.029.

34. K.I. Ereifej, H. Feng, T.M. Rababah, S.H. Tashtoush, M.H. Al-U'datt, S. Gammoh and G.J. Al-Rabadi, Food and Nutrition Sciences, 7, 5(2016), DOI: 10.4236/fns.2016.75038.

35. M.A. Hossain, and M.D. Shah, Arabian Journal of Chemistry, 8, 1(2015), DOI: 10.1016/j.arabjc.2011.01.007.

36. P. Molyneux, Songklanakarin Journal of Science and Technology, 26, 2(2004), DOI: 10.1287/isre.6.2.144.

[RJC- 5584/2019] 